Vol 1 No 22020 Desember 2020

Jurnal AlphaEuclidEdu

Received: 21/10/2020; Revised: 24/11/2020; Accepted: 04/12/2020

\title{
EKSPLORASI KETERAMPILAN KERUANGAN MENGENAI KUBUS MELALUI WAWANCARA KLINIS BERBASIS MASALAH
}

\author{
${ }^{1}$ Medellu, Antonius, ${ }^{2}$ Sugiatno, ${ }^{3}$ Hartoyo, Agung \\ ${ }^{1,2,3}$ Pendidikam Matematika FKIP Universitas Tanjungpura Pontianak \\ Email: anton.medellu@yahoo.com
}

\begin{abstract}
Abtract
Students' spatial skills in solving problems related to the arrangement of cubes were relatively low. This research was conducted to describe students' spatial skills regarding cube arrangement through problembased clinical interviews. The design of this study was descriptive exploratory using one class of students as the research sample. Student tests were used to see students' initial abilities regarding cube arrangements. While problem-based clinical interviews were used to dig deeper into spatial skills and student problem solving regarding cube arrangements. The data obtained was processed using descriptive statistics such as average, cumulative frequency and percent score. Furthermore, the data was analyzed and interpreted using qualitative data analysis techniques to explain the phenomena that occur in the field. The results of the study show that the students' spatial skills regarding the cube were still relatively low; students' spatial skills were not in accordance with the concepts related to solving the problem of unit cube arrangements; students' spatial skills did not show skills related to solving problems in unit cube arrangements; to transform students' skills into spatial skills related to the problem of cube arrangement it is necessary to re-emphasize spatial skills which include spatial visual, spatial perception, spatial relations, and spatial orientation.
\end{abstract}

Keywords: Spatial Ability, Problem Based Clinical Interview

\section{Pendahuluan}

Nilai rata-rata Ujian Nasional (UN) matematika sekolah menengah pertama tahun pelajaran 2014/2015 adalah 56,28. Hasil ini merupakan nilai terendah dari seluruh mata pelajaran Ujian Nasional yang telah dilaksanakan (Kemendikbud, 2015). Hasil ini juga menunjukan rendahnya kemampuan pemecahan masalah matematika di tingkat sekolah menengah pertama. Di tingkat internasional hasil penelitian Trends in International Mathematics and Science Study (TIMSS) tahun 2011 menempatkan literasi matematika siswa SMP di Indonesia berada pada urutan ke-38 dari 42 negara (Balitbang, 2012). Hasil yang tidak jauh berbeda termuat dalam survey Programme for International Student Assessment (PISA) tahun 2012 yang menyimpulkan bahwa literasi matematika siswa Indonesia berada pada urutan 64 dari 65 negara (Balitbang, 2012). PISA juga mengungkapkan bahwa siswa Indonesia lemah dalam konsep-konsep geometri, khususnya yang berkaitan dengan pemahaman ruang dan bentuk. Sebagai ilustrasi, siswa menghadapi kesulitan dalam membayangkan bangun ruang balok yang memiliki rongga di dalamnya (Balitbang, 2012).

Salah satu kompetensi yang ingin dicapai dalam kurikulum pendidikan nasional di jenjang sekolah menengah adalah kompetensi keterampilan yang bertujuan agar siswa memiliki kemampuan untuk mencoba, mengolah, dan menyaji dalam ranah konkret (menggunakan, mengurai, merangkai, memodifikasi, dan membuat) serta ranah abstrak (menulis, membaca, menghitung, menggambar, dan mengarang) (Permendikbud, 2016). 
National Council of Teachers of Mathematics (NCTM) merekomendasikan beberapa tujuan umum siswa belajar matematika, yaitu: (1) belajar akan nilai-nilai matematika, memahami evolusi dan peran-annya dalam masyarakat dan sains; (2) percaya diri pada kemampuan yang dimiliki, percaya pada kemampuan berpikir matematis yang dimiliki dan peka terhadap situasi dan masalah; (3) menjadi seorang problem solver, menjadi warga negara yang terampil, produktif dan berpengalaman dalam memecahkan berbagai permasalahan; (4) belajar berkomunikasi secara matematis, belajar tentang simbol, lambang dan kaidah matematis; (5) belajar bernalar secara matematis yaitu membuat konjektur, bukti dan membangun argumen secara matematik (NCTM, 2000).

E.T. Russefendi (2005) mengemukakan aritmatika, aljabar, kalkulus dan geometri merupakan bagian matematika yang timbul karena pikiran-pikiran manusia yang berhubungan dengan ide, proses, dan penalaran. Geometri diajarkan di sekolah berguna untuk meningkatkan cara berpikir logis dalam membuat generalisasi secara benar. Agar dapat memahami aritmatika, aljabar, dan kalkulus, maka pemahaman konsep geometri harus dikuasai secara mendalam.

Pembelajaran geometri di pendidikan dasar dan menengah dimulai dari obyek konkret ke obyek abstrak, dari segi intuitif ke analisis, dari eksplorasi (penemuan) ke penguasaan (pemahaman), serta dari tahap yang paling sederhana hingga ke tahap yang lebih kompleks. Van Hiele menyimpulkan bahwa anak-anak dalam belajar geometri melalui beberapa tahap yaitu: visualisasi, analisis, abstraksi, deduksi, dan akurasi. Gabungan dari waktu, materi pelajaran, dan metode pengajaran yang dipakai akan meningkatkan kemampuan berpikir siswa ke tahap yang lebih tinggi (Mason, 1998).

Beberapa penelitian menyimpulkan bahwa materi geometri merupakan materi yang tergolong sulit. Hal ini dapat dilihat dari hasil Ujian Nasional SMP Tahun Pelajaran 2014/2015 dimana materi bangun geometris menempati posisi terendah dibandingkan materi lainnya (Tabel 1).

Tabel 1.

Persentase Penguasaan Materi Soal Matematika Ujian Nasional SMP Tahun Pelajaran $2014 / 2015$

\begin{tabular}{ccc}
\hline Nomor Urut & Materi Yang Diuji & Persentase \\
\hline 1 & Statistika dan Peluang & 60,78 \\
\hline 2 & Operasi Bilangan & 60,64 \\
\hline 3 & Operasi Aljabar & 57,28 \\
\hline 4 & Bangun Geometris & 52,04 \\
\hline
\end{tabular}

Keterampilan keruangan adalah bagian dari keterampilan geometri yang berkaitan dengan bangun ruang. Keterampilan dasar dalam geometri merupakan prasyarat untuk mempelajari konsep-konsep keruangan. Menurut Fennama dan Sherman (2000) keterampilan keruangan merupakan suatu bakat yang diperoleh dengan memanipulasi mental terhadap benda padat. Bakat ini muncul sebagai komponen keterampilan matematis dan memperlihatkan besarnya korelasi keterampilan visual terhadap prestasi belajar matematika sebagaimana keterampilan verbal. Catel (Ruseffendi, 2006) menyatakan salah satu persoalan matematika adalah munculnya tuntutan bagi siswa 
untuk menggunakan keterampilan nalar dan berpikir kritisnya dalam memecahkan masalah-masalah yang berkaitan dengan keruangan. Schonberger (Saragih, 2011) mengemukakan bahwa keterampilan keruangan adalah salah satu komponen utama dari kecerdasan manusia dan memiliki peran penting dalam beberapa program penempatan dan pelatihan. Hofter (1998) mengemukakan lima keteram-pilan dasar dalam belajar geometri keruangan. Kelima keterampilan tersebut meliputi: (1) Keterampilan visual, yaitu kemampuan untuk mengenal dan mengamati bangun ruang serta keterkaitannya satu dengan yang lain, kemampuan untuk mengklasifikasikan bangun geometri menurut ciri-ciri yang teramati, kemampuan untuk menyimpulkan informasi berdasarkan pengamatan visual, dan kemampuan untuk memvisualisasikan model geometri atau contoh-contoh penangkal dalam suatu sistem matematika deduktif; (2) Keterampilan verbal, yaitu kemampuan untuk menunjukkan bermacam bangun geometri menurut namanya, kemampuan untuk memvisualisasikan bangun geometri menurut deskripsi verbalnya, kemampuan untuk mengungkapkan sifat-sifat bangun geometri, merumuskan definisi dengan tepat dan benar, mengungkapkan hubungan antar bangun, kemampuan untuk mengenali struktur logis dari masalah verbal, merumuskan generalisasi dan abstraksi; (3) Keterampilan menggambar, yaitu kemampuan untuk mensketsa gambar bangun ruang menurut deskripsi verbalnya, kemampuan untuk menggambar atau mengkonstruksi bangun ruang berdasarkan sifat yang diberikan, kemampuan untuk mengkonstruksi gambar bangun ruang yang memiliki kaitan tertentu; (4) Keterampilan logika, yaitu kemampuan untuk mengenal perbedaan dan kesamaaan antar bangun geometri, kemampuan untuk menentukan apakah sebuah gambar masuk atau tidak masuk dalam kelas tertentu, kemampuan untuk memahami dan menerapkan sifat-sifat penting dari definisi, menujukkan akibat-akibat logis dari data yang diberikan, mengembangkan bukti yang logis, dan mengenal peranan dan keterbatasan metode deduktif; (5) Keterampilan terapan, yaitu kemampuan untuk mengenal model fisik dari bangun geometri, kemampuan untuk mensketsa atau mengkonstruksi model geometri berdasarkan objek fisiknya, kemampuan untuk menerapkan sifat-sifat dari model geometri dari objek fisik, kemampuan untuk mengembangkan model geometri bagi fenomena alam, dan kemampuan untuk menerapkan model-model geometri dalam pemecahan masalah.

Hasil studi PISA menyimpulkan hanya $33,4 \%$ siswa Indonesia yang mampu menjawab soal-soal geometri yang berkaitan dengan bentuk dan ruang (Wardhani dan Rumiati, 2011). Sementara prinsip pertama NCTM menyatakan bahwa keunggulan pembelajaran matematika memerlukan kesetaraan, harapan yang besar, dan dukungan yang kuat untuk semua siswa (NCTM, 2000). Prinsip ini mengindikasikan harapan yang tinggi untuk semua siswa. Semua siswa harus memiliki kesempatan dan dukungan yang cukup untuk belajar matematika, tanpa memandang karakteristik personal, latar belakang, ataupun hambatan fisik. Hal ini berarti bahwa siswa yang berkemampuan rendah harus ditangani terlebih dulu agar memiliki kemampuan cukup untuk mengikuti pembelajaran matematika. 
Vol 1 No 22020 Desember 2020

Jurnal AlphaEuclidEdu

Salah satu model pembelajaran yang dapat ditawarkan untuk mengatasi rendahnya kemampuan matematis siswa adalah metode pembelajaran wawancara klinis. Wawancara klinis memiliki kekuatan untuk menghimpun sekaligus menganalisis proses mental yang terjadi dalam pikiran siswa serta mampu menelusuri berbagai struktur kognitif yang masih tersembunyi dalam pikiran siswa (Clement, 2000). Ambrosse, dkk (2003) menyatakan wawancara klinis dapat diguna-kan para guru untuk memahami cara berpikir matematis siswa. Menurut Ginsburg (2009) wawancara klinis merupakan salah satu metode yang dapat digunakan untuk mengumpulkan data tentang hasil belajar siswa dalam penilaian formatif selain observasi dan pengujian (tes). Wawancara klinis merupakan metode yang efektif untuk menghasilkan informasi yang esensial mengenai proses kognitif yang terjadi dalam diri siswa saat ia mengerjakan sesuatu.

Terdapat beberapa studi mengenai wawancara klinis yang dapat dipakai untuk mengatasi kesulitan belajar, antara lain Lusiana (2012), Christianti (2012), dan Robeka (2012). Hasil studi yang mereka lakukan meyimpulkan bahwa wawancara klinis dapat mengurangi kesulitan belajar matematika siswa rata-rata sebesar 70\% $\square$ 90\%. Dari hasil studi ini, terlihat bahwa begitu signifikannya wawancara klinis dalam me-ngurangi kesulitan belajar siswa. Namun demikian, wawancara klinis seperti itu dikata-kan lebih bersifat menggali pemahaman dan mengidentifikasi kesulitan belajar siswa ketimbang memperbaiki/menyembuhkan mis-konsepsi siswa (Francisco, 2000; Brown, 2004; Ginsburg, 2009).

\section{Metode Penelitian}

Jenis penelitian ini adalah deskriptif eksploratif yang bertujuan menggali keterampilan keruangan siswa mengenai kubus melalui wawancara klinis berbasis masalah. Arikunto (2006) menyatakan bahwa penelitian deskriptif eksplorarif bertujuan menggali sekaligus menggambarkan suatu fenomena, keadaan, atau gejala yang terjadi di lapangan. Sedangkan menurut Kotler dan Amstrong (2006), penelitian eksploratif adalah penelitian yang bertujuan menghimpun informasi awal yang akan membantu upaya menetapkan masalah dan merumuskan hipotesis.

Arikunto (2006) memberi batasan subyek penelitian sebagai benda, hal atau orang tempat dimana variabel penelitian melekat, dan yang dipermasalahkan. Dengan kata lain subyek penelitian adalah sesuatu yang di dalam dirinya melekat atau terkandung obyek penelitian. Berdasarkan uraian ini maka yang menjadi subyek penelitian dalam penelitian ini adalah siswa kelas VIIA SMP Gembala Baik Pontianak Tahun Pelajaran 2016/2017.

Prosedur dalam penelitian ini meliputi: (1) Melakukan tes tertulis dengan topik kubus satuan. (2) Menskor hasil pekerjaan siswa. (3) Mengelompokkan siswa ke dalam kelom-pok atas, kelompok tengah, dan kelompok bawah. (4) Mengidentifikasi jawaban siswa. (5) Memilih klien/responden dari masing-masing kelompok siswa untuk dilakukan wawancara. (6) Melakukan wawancara klinis berbasis masalah. Data yang didapat selanjutnya dianalisis dan diarahkan untuk mencapai tujuan penelitian. Karena jenis penelitian ini deskriptif eksploratif dengan pendekatan cenderung 
Vol 1 No 22020 Desember 2020

Jurnal AlphaEuclidEdu

kualitatif, maka analisa datanya menggunakan statistik deskriptif dan teknik analisa data kualitatif.

Penggunaan statistik deskriptif dimaksudkan untuk menganalisa data kuan-titatif dengan tujuan melihat persentase, frekwensi kumulatif, dan tendensi sentral data. Teknik analisa data kualitatif dimaksudkan untuk menjelaskan fenomena yang terindikasi dalam data. Menurut Miles dan Huberman (Moleong, 2009) terdapat tiga tahapan dalam teknik analisa data kualitatif, yaitu reduksi data (data reduction), penyajian data (data display) dan kesimpulan/verifikasi (conclussion drawing/verification).

Reduksi data (data reduction) berarti merangkum data, memilih hal-hal pokok dalam data, memfokuskan data pada hal yang penting, mencari pola dan tema data. Pada tahap ini dilakukan pemilihan tentang relevan atau tidaknya antara data dengan tujuan penelitian. Data atau informasi yang didapat dari lapangan merupakan bahan mentah yang harus diringkas, disusun secara sistematis, serta ditonjolkan pokok-pokok pentingnya sehingga lebih mudah dikendalikan.

Penyajian data (data display) yaitu menyajikan data dalam bentuk uraian singkat, bagan/tabel, hubungan antar katagori, dan sebagainya. Penyajian data yang digunakan dalam penelitian kualitatif bersifat naratif. Hal ini dimaksudkan untuk memahami fenomena yang terjadi, merencanakan kerja selanjutnya berdasarkan apa yang dipahami. Pada tahap ini data diklasifikasikan dan disajikan sesuai dengan pokok permasalahan yang diawali dengan pengkodean pada setiap subpokok permasalahan.

Kesimpulan/verifikasi (conclussion drawing/verification), kegiatan ini dimaksudkan untuk mencari makna data yang dilakukan dengan cara mencari hubungan, persamaan, atau perbedaan data. Penarikan kesimpulan dilakukan dengan cara membandingkan kesesuaian pernyataan dari subyek penelitian dengan makna yang terkandung dengan konsep-konsep dasar (landasan teori) dalam penelitian. Selanjutnya, agar analisis data mengarah pada tujuan penelitian maka disusunlah kuantifikasi data tentang keterampilan keruangan.

\section{Hasil Penelitian dan Pembahasan}

\subsection{Hasil Penelitian}

Hasil analisis butir soal tes menyimpulkan bahwa soal yang dianggap sukar adalah soal nomor $3 \mathrm{~b}$ dan soal nomor 5. Tingkat kesukaran kedua soal tersebut sebesar 32,50\% untuk soal nomor $3 \mathrm{~b}$ dan $6,88 \%$ untuk soal nomor 5 . Untuk soal nomor $3 \mathrm{~b}$, sebanyak $73 \%$ siswa sampel penelitian memperoleh skor 0,00 dan sebanyak $16 \%$ siswa sampel penelitian memperoleh skor maksimum 4,00. Hasil selengkapnya dapat dilihat pada Tabel 2 dan Tabel 3. Sebaliknya, soal tes yang dianggap mudah adalah soal nomor 3a. Tingkat kesukaran soal tersebut mencapai 65,00\%. Adapun jumlah siswa sampel penelitian menurut perolehan skor yang diraih untuk soal nomor 3a disajikan dalam Tabel 4.

Untuk siswa kelompok atas, rata-rata skor terendah berturut-turut berada pada butir soal nomor 5 dan nomor 2a. Rata-rata skor untuk butir soal nomor 5 sebesar 0,50 (skor 
Vol 1 No 22020 Desember 2020

Jurnal AlphaEuclidEdu

maksimum 8) dengan persen skor sebesar 6,3\% dan rata-rata skor sebesar 3,33 (skor maksimum 6) dengan persen skor sebesar 55,6\% untuk butir soal nomor 2a. Sedangkan rata-rata skor tertinggi siswa kelompok atas berturut-turut terjadi pada butir soal nomor 3a, nomor 4a dan nomor 4b. Rata-rata skor untuk butir soal nomor 3a sebesar 2,00 (skor maksimum 2) dengan persen skor sebesar 100,0\%, rata-rata skor untuk butir soal nomor 4a sebesar 3,00 (skor maksimum 3) dengan persen skor sebesar 100,0\% dan ratarata skor untuk butir soal nomor $4 \mathrm{~b}$ sebesar 3,00 (skor maksimum 3) dengan persen skor sebesar $100,0 \%$.

Tabel 2

Jumlah Siswa Berdasarkan Perolehan Skor Tes Awal untuk Soal Nomor 3b

\begin{tabular}{cccc}
\hline No & Skor & Jumlah Siswa & Persentase (\%) \\
\hline 1. & 0 & 27 & 73 \\
\hline 2. & 1 & 0 & 0 \\
\hline 3. & 2 & 4 & 11 \\
\hline 4. & 3 & 0 & 0 \\
\hline 5. & 4 & 6 & 16 \\
\hline Total & & 37 & 100 \\
\hline
\end{tabular}

Tabel 3

Jumlah Siswa Berdasarkan Perolehan Skor Tes Awal untuk Soal Nomor 5

\begin{tabular}{lccc}
\hline No & Skor & Jumlah Siswa & Persentase $(\%)$ \\
\hline 1. & 0 & 27 & 73 \\
\hline 2. & 1 & 3 & 8 \\
\hline 3. & 2 & 6 & 16 \\
\hline 4. & 3 & 0 & 0 \\
\hline 5. & 4 & 1 & 3 \\
\hline 6. & 5 & 0 & 0 \\
\hline 7. & 6 & 0 & 0 \\
\hline 8. & 7 & 0 & 0 \\
\hline 9. & 8 & 0 & 100 \\
\hline Total & & 37 & \\
\hline
\end{tabular}

Untuk siswa kelompok tengah, rata-rata skor terendah berturut-turut terjadi pada butir soal nomor $4 \mathrm{~b}$ dan nomor $4 \mathrm{a}$. Rata-rata skor untuk butir soal nomor $4 \mathrm{~b}$ sebesar 0,00 (skor maksimum 5) dengan persen skor sebesar 0,0\% dan rata-rata skor sebesar 0,13 (skor maksimum 3) dengan persen skor sebesar 4,17\% untuk butir soal nomor $4 \mathrm{a}$. Sedangkan rata-rata skor tertinggi siswa kelompok tengah, berturut-turut berada pada butir soal nomor 3a dan nomor 1a. Rata-rata skor untuk butir soal nomor 3a sebesar 1,37 (skor maksimum 2) dengan persen skor sebesar 58,3\% dan rata-rata skor untuk butir soal nomor 1a sebesar 2,33 (skor maksimum 4) dengan persen skor sebesar 58,3\%.

Untuk siswa kelompok bawah, rata-rata skor terendah berturut-turut berada pada butir soal nomor 1b, 1c, 2a, 2b, 3b, 4a dan 4b. Rata-rata skor untuk ketujuh butir soal tersebut adalah 0,00 dengan persen skor sebesar 0,0\%. Sedangkan rata-rata skor dan persen skor tertinggi yang diperoleh siswa kelompok bawah berada pada butir soal 
nomor 1a, nomor 3a dan nomor 5. Rata-rata skor 1,00 dan persen skor 25,0\% untuk soal nomor 1a, rata-rata skor 0,40 dan persen skor $10,0 \%$ untuk soal nomor 3 a, serta rata-rata skor 0,40 dan persen skor $10,0 \%$ untuk nomor 5 .

Dari Tabel 4 terlihat bahwa siswa kelompok atas memperoleh persen skor sempurna 100\% untuk butir soal nomor 3a, 4a dan 4b. Aspek keterampilan keruangan yang diukur oleh ketiga butir soal tersebut adalah spasial visual, spasial persepsi (yang meliputi ketetapan perseptual, persepsi terhadap posisi dalam ruang, persepsi terhadap hubungan keruangan), spasial relasi, dan spasial orientasi.

Persen skor rata-rata terendah siswa kelompok atas berturut-turut berada pada butir soal nomor 5, nomor 2a, dan nomor $2 \mathrm{~b}$. Adapun aspek keterampilan keruangan yang diukur oleh ketiga butir soal tersebut meliputi spasial visual, spasial persepsi (ketetapan perseptual dan persepsi terhadap hubungan keruangan), spasial relasi, dan spasial orientasi.

Tabel 4

Rata-rata Skor dan Persen Skor tiap Butir Soal Berdasarkan Kelompok Siswa

\begin{tabular}{|c|c|c|c|c|c|c|c|c|c|c|c|}
\hline \multirow{2}{*}{$\begin{array}{c}\text { Kelompok } \\
\text { Siswa }\end{array}$} & \multirow{2}{*}{ Aspek } & \multicolumn{10}{|c|}{ Nomor Soal (skor maks) } \\
\hline & & $1 \mathrm{a}(4)$ & $1 b(4)$ & $1 \mathrm{c}(4)$ & $2 \mathrm{a}(6)$ & $2 b(6)$ & $3 a(2)$ & $3 b(4)$ & $4 a(3)$ & $4 b(5)$ & $5(8)$ \\
\hline \multirow{2}{*}{ Atas } & $\begin{array}{l}\text { Rata-rata } \\
\text { Skor }\end{array}$ & 3,17 & 3,00 & 3,00 & 3,33 & 3,67 & 2,00 & 3,67 & 3,00 & 5,00 & 0,50 \\
\hline & Persen Skor & $79,2 \%$ & $75,0 \%$ & $75,0 \%$ & $55,6 \%$ & $61,1 \%$ & $100,0 \%$ & $91,7 \%$ & $100,0 \%$ & $100,0 \%$ & $6,3 \%$ \\
\hline \multirow{2}{*}{ Tengah } & $\begin{array}{l}\text { Rata-rata } \\
\text { Skor }\end{array}$ & 2,33 & 1,92 & 1,83 & 2,17 & 1,83 & 1,17 & 0,25 & 0,13 & 0,00 & 0,42 \\
\hline & Persen Skor & $58,3 \%$ & $47,9 \%$ & $45,8 \%$ & $36,2 \%$ & $30,6 \%$ & $58,3 \%$ & $6,25 \%$ & $4,17 \%$ & $0,0 \%$ & $5,2 \%$ \\
\hline \multirow[t]{2}{*}{ Bawah } & $\begin{array}{l}\text { Rata-rata } \\
\text { Skor }\end{array}$ & 1,00 & 0,00 & 0,00 & 0,00 & 0,00 & 0,40 & 0,00 & 0,00 & 0,00 & 0,40 \\
\hline & Persen Skor & $25,0 \%$ & $0,0 \%$ & $0,0 \%$ & $0,0 \%$ & $0,0 \%$ & $10,0 \%$ & $0,0 \%$ & $0,0 \%$ & $0,0 \%$ & $5,0 \%$ \\
\hline
\end{tabular}

Untuk siswa kelompok tengah persen skor tertinggi diperoleh pada butir soal nomor 1a sebesar 58,3\%, nomor 1 b sebesar $47,9 \%$, dan nomor 3a sebesar 58,3\%. Adapun aspek keterampilan keruangan yang diukur untuk butir soal nomor 1a adalah spasial visual dan spasial persepsi yang meliputi persepsi terhadap posisi dalam ruang serta persepsi terhadap hubungan keruangan. Sedangkan persen skor terendah siswa kelompok tengah diperoleh pada butir soal nomor 4 a sebesar $4,17 \%$, nomor 4 b sebesar $0,00 \%$, dan nomor 5 sebesar 5,2\%. Adapun aspek keterampilan keruangan yang diukur untuk butir soal nomor $4 \mathrm{a}$, nomor $4 \mathrm{~b}$ dan nomor 5 adalah spasial visual; spasial persepsi yang meliputi ketetapan perseptual, persepsi terhadap hubungan keruangan; spasial relasi; dan spasial orientasi.

Persen skor tertinggi siswa kelompok bawah diperoleh pada butir soal nomor 1a sebesar $25,0 \%$, nomor 3 a sebesar $10,0 \%$, dan nomor 5 sebesar 10,0\%. Sedangkan untuk butir soal nomor 1b, 1c, 2a, 2b, 3b, 4a, dan 4b masing-masing memperoleh persen skor sebesar $0,0 \%$. Hasil ini menunjukan bahwa siswa kelompok bawah memiliki keterampilan keruangan yang sangat rendah.

Hasil wawancara menyimpulkan bahwa siswa kelompok atas memberi jawaban/res-pon positif tentang kemampuan keruangan yang mereka pahami. Siswa kelompok tengah memberi jawaban/respon yang bervariasi mengenai kemampuan 
Vol 1 No 22020 Desember 2020

Jurnal AlphaEuclidEdu

keruangan siswa. Bervariasi artinya terdapat butir pertanyaan wawancara yang dijawab secara positif, namun ada pula yang dijawab secara negatif. Sedangkan untuk siswa kelompok bawah, hasil wawancara menyimpulkan bahwa mereka selalu memberi jawaban/respon yang negatif tentang kemampuan keruangan (spatial ability).

\subsection{Pembahasan}

\subsubsection{Analisis Hasil Tes Tertulis}

Proses penyelesaian tes tertulis oleh para siswa menghasilkan rata-rata pencapaian (daya serap) sebesar 31,6\%. Daya serap ini mengindikasikan rendahnya kemampuan siswa untuk menyelesaikan soal-soal yang berkaitan dengan susunan kubus. Daya serap ini juga menunjukkan kemampuan pemecahan masalah tentang kubus satuan belum tuntas diserap oleh sebagian besar siswa sampel penelitian (Kemendikbud, 2014).

Hasil analisis tes tertulis menyimpulkan bahwa soal yang dianggap sukar adalah soal nomor $3 \mathrm{~b}$ dan soal nomor 5. Berdasarkan hasil yang dicapai untuk soal nomor $3 \mathrm{~b}$ dapat disimpulkan bahwa sebagian besar siswa sampel penelitian tidak mampu menentukan banyak kubus satuan dalam bangun ruang berbentuk balok variatif tampak depan dan tampak samping. Sedangkan keterampilan keruangan yang tidak dikuasai untuk soal nomor 3b adalah: (1) Keterampilan logika: siswa tidak mampu memanipulasi ide-ide terkait untuk menghi-tung banyak kubus yang disajikan dalam gambar bangun ruang berbentuk balok variatif tampak depan dan tampak samping. (2) Keterampilan terapan: siswa tidak mampu menentukan hubungan konsep dan prinsip untuk menghitung banyak kubus yang disajikan dalam gambar bangun ruang berbentuk balok variatif tampak depan dan tampak samping (Hofter, 1998).

Untuk soal nomor 5 dapat disimpulkan bahwa sebagian besar siswa sampel penelitian tidak mampu menyelesaikan soal cerita kontekstual yang berkaitan dengan ukuran kotak (kubus/balok). Sedangkan keterampilan keruangan yang tidak dikuasai untuk soal tersebut adalah: (1) Keterampilan visual: siswa tidak mampu mengidentifikasi fakta melalui gambar, tidak mampu menafsirkan tanda-tanda (simbol/gambar) dan istilah, tidak mampu memanipulasi ide-ide terkait dan tidak mampu menyempurnakan hubung-an konsep dan prinsip yang berkaitan dengan volume balok/kubus.(2) Keterampilan logika: siswa tidak mampu menafsirkan tanda-tanda, simbol, gambar dan istilah bahwa siswa dapat menafsirkan persoalan yang dimaksud adalah susunan kubus dalam balok. (3) Keterampilan terapan: siswa tidak mampu memanipulasi ide-ide terkait bahwa untuk menghitung banyak kubus bahwa siswa dapat menghitungnya melalui banyak kubus tiap lapisan kemudian menjumlahkannya. Siswa tidak mampu menyempurnakan hubungan konsep dan prinsip bahwa untuk menghitung banyak kubus siswa dapat mengaitkannya dengan konsep volume balok panjang $\mathrm{x}$ lebar $\mathrm{x}$ tinggi.

Untuk siswa kelompok atas, rata-rata skor terendah berturut-turut berada pada butir soal nomor 5 dan nomor 2a. Sedangkan rata-rata skor tertinggi siswa kelompok atas berturut-turut terjadi pada butir soal nomor 3a, nomor 4a dan nomor 4b. Mengacu pada kisi-kisi butir soal nomor 5 dapat disimpulkan bahwa sebagian besar siswa kelompok 
atas: (1) tidak mampu mengidentifikasi fakta dalam soal cerita kontekstual menentukan kotak mana yang lebih besar. (2) tidak mampu menafsirkan tanda-tanda, simbol, gambar dan istilah yang termuat dalam soal cerita kontekstual menentukan kotak mana yang lebih besar. (3) tidak mampu memanipulasi ide-ide terkait dalam soal cerita kontekstual untuk menentukan kotak mana yang lebih besar. (4) tidak mampu menyempurnakan hubungan konsep dan prinsip bahwa untuk menghitung banyak kubus siswa dapat mengaitkannya dengan konsep volume balok panjang $\mathrm{x}$ lebar $\mathrm{x}$ tinggi.

Mengacu pada kisi-kisi butir soal nomor 2a dapat disimpulkan bahwa sebagian besar siswa kelompok atas: (1) cukup mampu mengidentifikasi fakta untuk menentukan banyak kubus dalam gambar balok yang tersusun dari kubus tidak lengkap. (2) cukup mampu menyempurnakan hubungan konsep dan prinsip untuk menentukan banyak kubus dalam gambar balok yang tersusun dari kubus tidak lengkap. Untuk menghitung banyak kubus tersebut siswa dapat mengaitkannya dengan konsep volume balok panjang $\mathrm{x}$ lebar $\mathrm{x}$ tinggi. Hitung masing-masing banyak kubus pada bagian panjang, lebar dan tingginya, kemudian dikalikan.

Berdasarkan hasil yang dicapai untuk butir soal nomor 3a, 4a dan $4 \mathrm{~b}$ dapat disimpulkan bahwa sebagian besar siswa kelompok atas: (1) mampu memanipulasi ideide terkait bahwa untuk menghitung banyak kubus siswa dapat menghitungnya melalui banyak kubus tiap lapisan kemudian menjumlahkannya. (2) mampu menyem-purnakan hubungan konsep dan prinsip bahwa untuk menghitung banyak kubus siswa dapat mengaitkannya dengan konsep volume balok panjang $\mathrm{x}$ lebar $\mathrm{x}$ tinggi.

Untuk siswa kelompok tengah, rata-rata skor terendah berturut-turut terjadi pada butir soal nomor $4 \mathrm{~b}$ dan nomor $4 \mathrm{a}$. Sedangkan rata-rata skor tertinggi siswa kelompok tengah,berturut-turut berada pada butir soal nomor 3a dan nomor 1a. Mengacu pada kisi-kisi butir soal nomor $4 \mathrm{~b}$ dan nomor 4a dapat disimpulkan bahwa siswa kelompok tengah: (1) tidak mampu memanipulasi ide-ide terkait bahwa untuk menghitung banyak kubus siswa dapat menghitungnya melalui banyak kubus tiap lapisan kemudian menjumlahkannya. (2) tidak mampu menyempurnakan hubungan konsep dan prinsip bahwa untuk menghitung banyak kubus siswa dapat mengaitkannya dengan konsep volume balok panjang $\mathrm{x}$ lebar $\mathrm{x}$ tinggi. Hitung masing-masing banyak kubus pada bagian panjang, lebar dan tingginya, kemudian dikalikan. Berdasarkan hasil yang dicapai untuk butir soal nomor 3a dapat disimpulkan bahwa sebagian besar siswa kelompok tengah: (1) cukup mampu memanipulasi ide-ide terkait bahwa untuk menghitung banyak kubus siswa dapat menghitungnya melalui banyak kubus tiap lapisan kemudian menjumlahkannya. (2) cukup mampu menyempurnakan hubungan konsep dan prinsip bahwa untuk menghitung banyak kubus siswa dapat mengaitkannya dengan konsep volume balok panjang x lebar x tinggi. Berdasarkan hasil yang dicapai untuk butir soal nomor 1a dapat disimpulkan bahwa sebagian besar siswa kelompok tengah: (1) cukup mampu mengidentifikasi fakta melalui gambar untuk menentukan banyak kubus satuan dalam balok yang tersusun dari kubus. (2) cukup mampu memanipulasi ide-ide terkait untuk menentukan banyak kubus satuan dalam balok yang tersusun dari kubus. Untuk menghitung banyak kubus tersebut, siswa dapat 
menghitungnya melalui banyak kubus tiap lapisan kemudian menjumlahkannya. (3) cukup mampu menyempurnakan hubungan konsep dan prinsip untuk menentukan banyak kubus satuan dalam balok yang tersusun dari kubus. Untuk menghitung banyak kubus siswa dapat mengaitkannya dengan konsep volume balok panjang $\mathrm{x}$ lebar $\mathrm{x}$ tinggi. Hitung masing-masing banyak kubus pada bagian panjang, lebar dan tingginya, kemudian dikalikan.

Untuk siswa kelompok bawah, rata-rata skor terendah berturut-turut berada pada butir soal nomor 1b, 1c, 2a, 2b, 3b, 4a dan 4b. Sedangkan rata-rata skor dan persen skor tertinggi yang diperoleh siswa kelompok bawah berada pada butir soal nomor 1a, nomor 3a dan nomor 5. Berdasarkan hasil tersebut dapat disimpulkan bahwa siswa kelompok bawah: (1) tidak mampu mengidentifikasi fakta melalui gambar bahwa gambar balok tersusun dari kubus. (2) tidak mampu memanipulasi ide-ide terkait bahwa untuk menghitung banyak kubus siswa dapat menghitungnya melalui banyak kubus tiap lapisan kemudian menjumlahkannya. (3) tidak mampu menyempurnakan hubungan konsep dan prinsip bahwa untuk menghitung banyak kubus siswa dapat mengaitkannya dengan konsep volume balok panjang $\mathrm{x}$ lebar $\mathrm{x}$ tinggi. Hitung masing-masing banyak kubus pada bagian panjang, lebar dan tingginya, kemudian dikalikan. (4) tidak mampu mengidentifikasi fakta melalui gambar bahwa gambar balok tersusun dari kubus. (5) tidak mampu menyempurnakan hubungan konsep dan prinsip bahwa untuk menghitung banyak kubus siswa dapat mengaitkannya dengan konsep volume balok panjang $\mathrm{x}$ lebar $\mathrm{x}$ tinggi. Hitung masing-masing banyak kubus pada bagian panjang, lebar dan tingginya, kemudian dikalikan. (6) tidak mampu memanipulasi ide-ide terkait bahwa untuk menghitung banyak kubus siswa dapat menghitungnya melalui banyak kubus tiap lapisan kemudian menjumlahkannya. (7) tidak mampu menyempurnakan hubungan konsep dan prinsip bahwa untuk menghitung banyak kubus siswa dapat mengaitkannya dengan konsep volume balok panjang $\mathrm{x}$ lebar $\mathrm{x}$ tinggi. Analisis Kemampuan

\section{Keruangan Siswa}

Siswa kelompok atas memperoleh persen skor sempurna $100 \%$ untuk butir soal nomor 3a, 4a dan 4b. Berkaitan dengan hasil tersebut dapat ditarik kesimpulan bahwa siswa kelompok atas: (1) memiliki kemampuan spasial visual tentang susunan kubus sederhana maupun variatif, yaitu: kemampuan untuk mengamati dan membayangkan bentuk susunan kubus sederhana atau variatif berdasarkan stimulus yang diberikannya. Stimulus atau rangsangan ini dapat berupa rotasi, pembalikan, perubahan orientasi (misal perubahan arah penglihatan), atau stimulus lainnya. Hal ini sejalan dengan pendapat Thurstone (Mohler, 2008) yang menyatakan bahwa visualisasi spasial yang didefinisikan sebagai kemampuan untuk mengenali bagian-bagian objek jika objek tersebut bergerak atau dipindahkan dari posisi semula. (2) memiliki kemampuan spasial persepsi tentang susunan kubus sederhana maupun variatif, yaitu kemampuan untuk mengenal dan membedakan stimulus yang berkaitan dengan susunan kubus sederhana maupun variatif, dimana untuk menginterpretasikannya, stimulus tersebut dikaitkan dengan pengalaman masa lalu. Hal ini didukung oleh pendapat De Grade (1987) serta Frostig \& Horner (Saragih, 2011). Kemampuan spasial persepsi tentang susunan kubus 
sederhana maupun variatif ini terdiri dari: ketetapan perseptual (perceptual constancy), persepsi terhadap posisi dalam ruang (position in spatial perception), (c) Persepsi terhadap hubungan keruangan (Perception of spatial relationship), yaitu kemampuan untuk melihat dua atau lebih susunan kubus sederhana/variatif dan kaitannya satu sama lain. Kemampuan untuk menentukan banyak kubus dalam susunan kubus sederhana maupun variatif. (3) memiliki kemampuan spasial relasi, yaitu kemampuan untuk menyatakan kedudukan dua atau lebih kubus. Kemampuan yang berkaitan dengan hubungan kedudukan dua atau lebih kubus, seperti kubus mana yang berada pada posisi depan dan belakang, kubus mana yang berada dalam satu baris, kubus mana yang berhadapan, dan lain sebagainya (Elliot, 2005; De Guire dalam Saragih 2011). (4) memiliki kemampuan spasial orientasi, yaitu kemampuan untuk mengenal susunan atau bentuk kubus secara umum dengan membayangkan perubahan perspektif kubus. Kemampuan spasial orientasi merupakan kemampuan membayangkan (tanpa gambar) susunan kubus sederhana maupun variatif (Elliot, 2005; Kimura, 2005; De Guire dalam Saragih, 2011).

Persen skor rata-rata terendah siswa kelompok atas berturut-turut berada pada butir soal nomor 5, nomor $2 \mathrm{a}$, dan nomor $2 \mathrm{~b}$. Berdasarkan perolehan persen skor rata-rata butir soal nomor 5 dapat disimpulkan bahwa siswa kelompok atas: (1) tidak memiliki kemampuan spasial visual dalam kaitan menyelesaikan soal cerita kontekstual yang berkaitan dengan kubus. Tidak memiliki kemampuan untuk mengamati dan membayangkan penyelesaian soal cerita kontekstual yang berkaitan dengan kubus berdasarkan stimulus/rangsangan yang diberikannya. (2) tidak memiliki kemampuan spasial persepsi untuk menyelesaikan soal cerita kontekstual yang berkaitan dengan kubus. Ketidakmampuan untuk mengenal dan membedakan stimulus yang berkaitan dengan soal cerita kontekstual yang berhubungan dengan kubus, dimana untuk menginterpretasikannya, stimulus tersebut dikaitkan dengan pengalaman masa lalu. (3) tidak memiliki kemampuan spasial relasi, yaitu ketidakmampuan untuk menyatakan hubungan benda ruang kubus dalam soal cerita kontekstual. (4) tidak memiliki kemampuan spasial orientasi, yaitu ketidakmampuan untuk mengenal susunan atau bentuk kubus secara umum dengan membayangkan perubahan perspektif kubus. Kemampuan spasial orientasi merupakan kemampuan membayangkan (tanpa gambar) susunan kubus dalam soal cerita kontekstual.

Berdasarkan perolehan persen skor rata-rata butir soal nomor $2 \mathrm{a}$ dan $2 \mathrm{~b}$ dapat disimpulkan bahwa siswa kelompok atas: (1) tidak memiliki kemampuan spasial visual dalam kaitan menentukan banyak kubus pada gambar balok yang terbentuk dari susunan kubus tidak lengkap. Tidak memiliki kemampuan mengamati dan membayangkan untuk menentukan banyak kubus pada gambar balok yang terbentuk dari susunan kubus tidak lengkap berdasarkan stimulus/rangsangan yang diberikannya. (2) tidak memiliki kemampuan spasial persepsi untuk menentukan banyak kubus pada gambar balok yang terbentuk dari susunan kubus tidak lengkap. Ketidakmampuan untuk mengenal dan membedakan stimulus yang berkaitan dengan menentukan banyak kubus pada gambar balok yang terbentuk dari susunan kubus tidak lengkap, dimana untuk 
menginterpretasikannya, stimulus tersebut dikaitkan dengan pengalaman masa lalu. (3) tidak memiliki kemampuan spasial relasi, yaitu ketidakmampuan untuk menyatakan hubungan banyak kubus pada gambar balok yang terbentuk dari susunan kubus tidak lengkap dengan aspek-aspek keruangan.

Untuk siswa kelompok tengah persen skor tertinggi diperoleh pada butir soal nomor 1a sebesar 58,3\%, nomor 1 b sebesar 47,9\%, dan nomor 3a sebesar 58,3\%. Berdasarkan persen skor butir soal nomor 1a dan 1b dapat disimpulkan bahwa siswa kelompok tengah: (1) cukup memiliki kemampuan spasial visual untuk menentukan banyak kubus dalam balok yang tersusun dari kubus. Cukup mampu untuk mengamati dan membayangkan banyak kubus pada balok berdasarkan stimulus yang diberikannya. (2) cukup memiliki kemampuan spasial persepsi tentang banyak kubus dalam balok yang tersusun dari kubus. Cukup mampu untuk mengenal dan membedakan stimulus yang berkaitan dengan menentukan banyak kubus dalam balok yang tersusun dari kubus, dimana untuk menginterpretasikannya, stimulus tersebut dikaitkan dengan pengalaman masa lalu.

Persen skor terendah siswa kelompok tengah diperoleh pada butir soal nomor $4 \mathrm{a}$ sebesar 4,17\%, nomor 4 b sebesar $0,00 \%$, dan nomor 5 sebesar 5,2\%. Berdasarkan persen skor butir soal nomor $4 \mathrm{a}$ dan $4 \mathrm{~b}$ dapat disimpulkan siswa kelompok tengah: (1) tidak memiliki kemampuan spasial visual tentang susunan kubus variatif. Ketidakmampuan untuk mengamati dan membayangkan bentuk susunan kubus variatif berdasarkan stimulus yang diberikannya. (2) siswa kelompok tengah tidak memiliki kemampuan spasial persepsi tentang susunan kubus variatif. Ketidakmampuan untuk mengenal dan membedakan stimulus yang berkaitan dengan susunan kubus variatif.

Berdasarkan persen skor butir soal nomor 5 dapat disimpulkan bahwa siswa kelompok tengah: (1) tidak memiliki kemampuan spasial visual dalam kaitan menyelesaikan soal cerita kontekstual yang berkaitan dengan kubus. Tidak memiliki kemampuan untuk mengamati dan membayangkan penyelesaian soal cerita kontekstual yang berkaitan dengan kubus berdasarkan stimulus yang diberikannya. (2) tidak memiliki kemampuan spasial persepsi untuk menyelesaikan soal cerita kontekstual yang berkaitan dengan kubus.

Persen skor tertinggi siswa kelompok bawah diperoleh pada butir soal nomor 1a sebesar 25,0\%, nomor 3a sebesar 10,0\%, dan nomor 5 sebesar 10,0\%. Sedangkan untuk butir soal nomor 1b, 1c, 2a, 2b, 3b, 4a, dan 4b masing-masing memperoleh persen skor sebesar 0,0\%. Hasil ini menunjukan bahwa siswa kelompok bawah memiliki kemampuan keruangan yang sangat rendah bahkan dapat dikatakan tidak memiliki kemampuan keruangan sama sekali. Hasil-hasil tersebut juga menyimpulkan bahwa siswa kelompok bawah: (1) tidak memiliki kemampuan spasial visual untuk menentukan banyak kubus pada balok, baik sederhana maupun variatif, baik lengkap maupun tidak lengkap yang dilihat dari berbagai sisi. Tidak memiliki kemampuan spasial visual untuk menentukan penyelesaian soal cerita kontekstual yang berkaitan dengan memilih dua kotak (balok/kubus) mana yang lebih besar. (2) tidak memiliki kemampuan spasial persepsi untuk menentukan banyak kubus pada balok, baik 
sederhana maupun variatif, baik lengkap maupun tidak lengkap yang dilihat dari berbagai sisi. Tidak memiliki kemampuan spasial persepsi untuk menentukan penyelesaian soal cerita kontekstual yang berkaitan dengan memilih dua kotak (balok/kubus) mana yang lebih besar. Hal ini berarti pula siswa kelompok bawah tidak memiliki kemampuan ketetapan perseptual (perceptual constancy), yaitu ketidakmampuan mengenal bahwa untuk menentukan banyak kubus pada balok, baik sederhana maupun variatif, baik lengkap maupun tidak lengkap yang dilihat dari berbagai sisi, memiliki struktur yang jelas.

\subsubsection{Analisis Keterampilan Keruangan Berdasarkan Wawancara Klinis Berbasis Masalah}

Dari tiga orang siswa kelompok atas yang terpilih sebagai klien, didapatkan jawaban/respon positif tentang keterampilan dan kemampuan keruangan (spatial ability) yang mereka pahami. Jawaban positif berarti siswa memberikan jawaban berupa penjelasan sesuai pengetahuan atau penalaran yang mereka miliki. Sedangkan jawaban/respon negatif adalah jawaban/respon singkat yang diberikan siswa, seperti "Tidak tahu”, "Lupa”, "Tidak ingat" dan lain sebagainya atau jawaban lain yang tidak sesuai dengan indikator jawaban yang diharapkan. Dari jawaban klien siswa kelompok atas, terlihat bahwa siswa mencoba mengkonsepsi kembali bangun ruang kubus dengan cara membayangkan menurut pengalaman mereka. Walaupun jawaban ketiga siswa tidak sama persis dengan definisi formal kubus, namun dapat disimpulkan bahwa siswa kelompok atas memiliki keterampilan verbal dan kemampuan orientasi keruangan yang positif untuk menjelaskan bangun ruang kubus secara verbal.

Siswa kelompok tengah berjumlah 24 orang. Secara umum, dari siswa kelompok tengah didapatkan jawaban/respon yang bervariasi mengenai keterampilan keruangan siswa. Untuk beberapa keterampilan keruangan seperti keterampilan verbal dan keterampilan orientasi bernilai positif. Tetapi keterampilan logika, terapan dan persepsi terhadap ruang bernilai negatif.

Siswa kelompok bawah berjumlah 5 orang. Secara umum, dari tiga orang siswa kelompok bawah yang terpilih sebagai klien, didapatkan jawaban/respon yang negatif tentang keterampilan dan kemampuan keruangan (spatial ability). Siswa kelompok bawah tidak memiliki kemampuan dalam menentukan posisi dua rusuk pada kubus (keterampilan verbal, terapan, relasi) dan tidak mampu menentukan rumus volume kubus (keterampilan perseptual).

\section{Kesimpulan}

Dari hasil penelitian dan pembahasan maka dapat disimpulkan:

1. Keterampilan keruangan siswa mengenai kubus masih tergolong rendah. Siswa tidak memiliki konsep yang jelas tentang kubus atau kubus satuan. Hal ini menunjukan bahwa keterampilan visual siswa mengenai kubus atau susunan kubus masih rendah: Siswa tidak dapat mengidentifikasi fakta-fakta (melalui gambar) bahwa suatu gambar tersusun dari beberapa kubus, tidak dapat mengenali apakah suatu bangun ruang merupakan kubus atau bukan, apakah suatu bangun ruang terbentuk dari susunan 
kubus atau tidak. Keterampilan verbal siswa mengenai kubus atau kubus satuan masih rendah: Siswa tidak dapat menyebutkan definisi formal kubus/kubus satuan berdasarkan ciri, karakteristik dan gambar fisiknya, tidak dapat menjelaskan secara verbal (lisan/tulisan) keterkaitan kubus/kubus satuan satu terhadap lainnya, tidak mampu menjelaskan secara verbal (lisan/tulisan) keterkaitan konsep dan prinsip susunan bangun ruang yang terbentuk dari susunan kubus. Keterampilan logika siswa mengenai kubus atau kubus satuan masih rendah: Siswa tidak dapat mengidentifikasi kesamaan/perbedaan bangun ruang yang berkaitan dengan susunan kubus, tidak dapat mengidentifikasi sifat-sifat penting dari definisi, konsep, prinsip bangun ruang yang berkaitan dengan susunan kubus, tidak dapat mengidentifikasi implikasi logis dari informasi yang diberikan pada bangun ruang yang berkaitan dengan susunan kubus. Keterampilan terapan siswa mengenai kubus atau kubus satuan masih rendah: Siswa tidak dapat mengkonstruksi susunan kubus berdasarkan gambar objek fisiknya, tidak dapat menerapkan sifat-sifat geometri pada objek fisik kubus atau susunan kubus untuk menyelesaikan masalah.

2. Konsepsi siswa tidak sesuai dengan konsep yang terkait dengan penyelesaian masalah susunan kubus satuan. Hal ini berarti Siswa tidak mampu memanipulasi ideide terkait bahwa untuk menghitung banyak kubus. Siswa dapat menghitungnya melalui banyak kubus tiap lapisan kemudian menjumlahkannya. Siswa tidak mampu menyempurnakan hubungan konsep dan prinsip bahwa untuk menghitung banyak kubus siswa dapat mengaitkannya dengan konsep volume balok panjang $\mathrm{x}$ lebar $\mathrm{x}$ tinggi.

3. Konsepsi siswa tidak menunjukkan keterampilan yang terkait dengan penyelesaian masalah susunan kubus satuan. Hal ini menunjukkan bahwa: Siswa cenderung menggunakan pemahamannya sendiri untuk menyelesaikan masalah yang berkaitan dengan susunan kubus. Siswa secara intuitif menemukan penyelesaian masalah yang berkaitan dengan susunan kubus satuan. Siswa cenderung menebak untuk menemukan penyelesaian masalah yang berkaitan dengan susunan kubus satuan.

\section{Referensi}

Ambrose, R., dkk. (2003). Exploring The Use of Clinical Interviews in Teacher Development. American Educational Research Association. Chicago, IL.

Batista, M . T \& Clements, D. H. (1996). Student's Understanding of Threedimensional Rectangular Arrays of Cubes. Journal for Research in Mathematics Education, Vol. 27, No. 3.258-292.

Bishop, A.J. (1993). Spatial Abilities and Mathematics Education - a Review in Education Studies in Mathematics. D. Riedle Publishing Co. USA.

Black, A.A. (2005). Spatial Ability and Earth Science Conceptual Understanding. Springfield: Missioury State University. Tersedia: aab208f@smsu.edu [10 Januari 2012].

Brown, Nathaniel J. S. (2004). Performance Analysis: Characterizing Knowing In A Clinical Interview. San Diego: American Educational Research Association. 
Vol 1 No 22020 Desember 2020

Jurnal AlphaEuclidEdu

Caroll, J. B. (1993). Human Cognitive Abilities. A Survey of Factor Analytic Studies. New York: Cambridge University Press.

Christianti, Tarsila. (2012). Mengatasi Kesulitan Siswa Dalam Menyelesaikan Limit Fungsi Aljabar Menggunakan Wawancara Klinis Di Kelas XI SMA Benediktus Pahauman. Pontianak: Skripsi pada PS Pendidikan Matematika. STKIP PGRI.

Ginsburg, Herbert P. (2009). The Challenge of Formative Assessment in Mathematics Education: Children's Minds, Teachers' Minds. S. Karger AG, Basel.

Kemendikbud, (2016). Laporan Hasil Ujian Nasional SMP/MTs Tahun Pelajaran 2014/2015. Jakarta: Kemendikbud.

Mohler, J. L. (2008). A Review of Spatial Abilities Research. Engeneering Design Graphics Journal.

Moleong , Lexy J. (2009) Metodologi Penelitian Kualitatif. Bandung: Remaja Rosdakarya.

Moyer, Patricia dan Milewics, Elizabeth. (2002). Journal of Mathematics Teacher Education. Learning To Questions: Theoritical Perspective. Netherlands: Kluwer Academic Publishers.

National Council of Teachers of Mathematics. (2000). Principles and Standards for School Mathematics. Reston: VA NCTM.

Olkun, S. (2003). Making Connection: Improving Spatial Abilities with Engeneering Drawing Activities. International Journal of Mathematics Teaching and Learning.

Supinah. (2008). Pengaruh Strategi Pembelajaran dan Gaya Berpikir terhadap Hasil Belajar Matematika Siswa Eksperimen pada Siswa SMP di Daerah Istimewa Yogyakarta. Yogyakarta: Disertasi pada UNY.

Surya, Hendra. (2011), Strategi Jitu Mencapai Kesuksesan Belajar. Jakarta: Kompas Gramedia PT Elex Media Komputindo.

Wahyudin. (2003). Ensiklopedia Matematika untuk SLTP. Jakarta: CV Tarity Samudra Berlian. 